\title{
Comparative catalytic activity of two plant proteinases upon caprine caseins in solution
}

\author{
Sofia V. Silva, F. Xavier Malcata* \\ Escola Superior de Biotecnologia, Universidade Católica Portuguesa, Rua Dr. António Bernardino de Almeida, 4200-072 Porto, Portugal
}

Keywords: Goat; Rennet substitute; Proteolysis; Electrophoresis; RP-HPLC

\begin{abstract}
The proteolytic activities of cardosins A and B, two (plant) proteinases from Cynara cardunculus, toward caprine caseins, independently, or in the presence of each other as Na-caseinate, were studied in a comparative fashion using polyacrylamide gel electrophoresis and reversed phase high performance liquid chromatography. The electrophoretic degradation patterns of both $\alpha_{\mathrm{s}}$ and $\beta$-casein, brought about by the cardosins, were similar to one another. In what concerns the specificity of these two enzymes upon caseinate, the major cleavage sites were Leu127-Thr128 and Leu190-Tyr191, both in $\beta$-casein. When caseins were tested

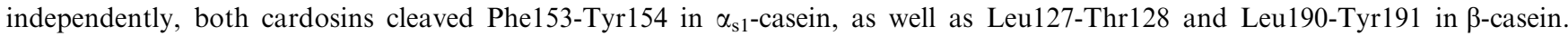

\section{Introduction}

Goats and sheep were among the first milk-producing animals to be domesticated, and milk produced by these small ruminants has been gaining considerable economic importance, particularly in Mediterranean countries, owing to the wider acceptance of cheeses obtained therefrom.

Proteolysis is beyond doubt the most important set of biochemical phenomena during ripening of most cheeses (Jin \& Park, 1996), and is carried out, to different extents, by proteolytic agents originating in milk, rennet (or rennet substitute), and starter and non-starter micro-organisms (Kelly, Fox \& McSweeny, 1996). Primary proteolysis is caused chiefly by residual rennet and produces large to medium-sized peptides from caseins; these can be further degraded into small peptides and eventually free amino acids, in processes known in whole as secondary proteolysis. Primary proteolysis plays an essential role in the development of proper cheese texture, whereas secondary proteolysis is often implicated with cheese flavour; it is thus of great

* Corresponding author. Tel:: + 351-225580004; fax: + 351-22509 0351 .

E-mail address: xmalcata@esb.ucp.pt (F.X. Malcata). importance to assure a well-balanced breakdown of curd proteins (caseins) in order to avoid formation of such undesired attributes in cheese as low viscosity and high bitterness (Visser, 1993).

Cynara cardunculus is a plant from the Asteracea family, a prickly variety of thistle similar to the globe artichoke (Roseiro, 1991), that grows wild and abundantly in several Mediterranean areas, as well as in the Canary and Madeira islands (Sanjuan \& FernandezSalguero, 1994). Aqueous extracts of the flowers of this plant have proven successful substitutes for animal rennet, and have accordingly been used for ages in the manufacture of goat's and ewe's milk cheeses in several rural areas of Portugal and Spain (Macedo, Malcata \& Oliveira, 1993). The clotting activity of those extracts is accounted for by two aspartic proteinases, tentatively named cardosin $\mathrm{A}$ and cardosin $\mathrm{B}$, which are present in the flowers of $C$. cardunculus in variable fractions depending on position; these enzymes are similar, in terms of specificity and activity, to chymosin and pepsin, respectively (Veríssimo, Esteves, Faro \& Pires, 1995).

Several analytical techniques have been extensively employed in the characterization of protein hydrolysates. Electrophoresis is one of the most accurate methods to monitor primary proteolysis, whereas high performance liquid chromatography (HPLC), using hydrophobic (or 
reverse phase) columns, has been found to be highly efficient in the separation of small peptides, and hence in monitoring secondary proteolysis, while providing useful information regarding their hydrophobicity (Silvestre, 1997).

The aim of this work was to compare the proteolytic activities of cardosins A and B upon goat's caseins, either in Na-caseinate or independently as $\alpha_{\mathrm{s}^{-}}$and $\beta$ caseins, using electrophoresis and reverse phase HPLC (RP-HPLC) as assay techniques. The study of casein breakdown in model systems will likely generate crucial information that will help to elucidate the complex processes involved in cheese ripening, and eventually contribute toward development of better final cheeses.

\section{Materials and methods}

\subsection{Preparation of substrate}

Whole caprine caseins were prepared via isoelectric precipitation of caprine milk by acidification to $\mathrm{pH} 4.25$ with $6 \mathrm{M} \mathrm{HCl}$, heating to $45^{\circ} \mathrm{C}$, holding at that temperature for $45 \mathrm{~min}$ and centrifugation at $6000 \mathrm{~g}$ for 10 min. The precipitate was recovered by filtration and washed several times with deionized water, and caseins were resuspended in deionized water (up to the same initial volume) with $\mathrm{pH}$ adjusted to 7.0 with $1 \mathrm{M}$ $\mathrm{NaOH}$. The system was allowed to equilibrate at $4{ }^{\circ} \mathrm{C}$ for at least $2 \mathrm{~h}$ before lyophilization; Na-caseinate was stored in this form until experimental use began.

Caprine $\alpha_{\mathrm{s} 1}{ }^{-}$and $\beta$-caseins were separated and purified following the method of Mercier, Maubois, Poznanski and Ribadeau-Dumas (1968), with modifications; these two casein families were prepared through fractionation of Na-caseinate $(0.1 \mathrm{~g}$ per $\mathrm{ml}$ of Tris- $\mathrm{HCl}$ buffer $)$ by chromatography in a column $(75 \times 2.5 \mathrm{~cm})$ using DEAEcellulose as stationary phase and $0.01 \mathrm{M}$ Tris- $\mathrm{HCl}$ buffer (pH 7.0), containing 4.5 M urea, 0.01 M imidazole and $0.1 \%(\mathrm{w} / \mathrm{v}) \beta$-mercaptoethanol, as mobile phase through a linear gradient of $0-0.4 \mathrm{M}$ sodium chloride within $7.5 \mathrm{~h}$ at $80 \mathrm{ml} / \mathrm{h}$. The experiments were carried out at room temperature. The $\alpha_{s}$ - and $\beta$-casein fractions obtained were independently pooled together, dialyzed against deionized water, lyophilized and stored prior to use.

\subsection{Preparation of enzyme}

The enzymes were obtained following the method of Veríssimo et al. (1995); the stigmae and stylets of dried flowers of $C$. cardunculus were separated and homogenized, using a mortar and pestle, at the ratio of $1 \mathrm{~g}$ of flowers per $12 \mathrm{ml}$ of aqueous $0.1 \mathrm{M}$ citric acid ( $\mathrm{pH} 3.0$ ). The homogenate was centrifuged at $6000 \mathrm{~g}$ for $20 \mathrm{~min}$; then a 2-ml aliquot of the supernatant was applied to a Highload 26/60 Sephacryl S-200 column (Pharmacia) after proper equilibration, and eluted with $20 \mathrm{mM}$ Tris$\mathrm{HCl}$ buffer $(\mathrm{pH} 7.6)$ at $1.5 \mathrm{ml} / \mathrm{min}$. Detection was by absorbance at $280 \mathrm{~nm}$. The fraction collected at the outlet stream, which corresponds to the proteinases of interest (i.e. to the peak of absorbance eluted at ca. $135 \mathrm{ml}$ ), was applied to a Mono Q HR 5/5 column (Pharmacia); elution proceeded with the same buffer at a flow rate of $0.75 \mathrm{ml} / \mathrm{min}$ under a linear gradient of $0-0.5 \mathrm{M} \mathrm{NaCl}$ within $30 \mathrm{~min}$; all fractions corresponding to peaks of absorbance were duly collected. Assay for purity was done via polyacrylamide gel electrophoresis with sodium dodecyl sulphate in a Phastsystem (Pharmacia) using PhastGel homogeneous 20.

\subsection{Quantification of protein}

Protein concentration was determined according to the method of Bradford (Robyt \& White, 1990). Bovine serum albumin (Merck) was used as standard in the preparation of the calibration curve.

\subsection{Performance of enzymatic hydrolysis}

Whole caseinate, $\alpha_{\mathrm{s}}$-caseins and $\beta$-caseins were independently dissolved in $100 \mathrm{mM}$ phosphate buffer ( $\mathrm{pH}$ 6.8) to a final concentration of $10 \mathrm{mg} / \mathrm{ml}$ and allowed to stabilize at $30^{\circ} \mathrm{C}$; sodium azide was then added at $0.05 \%$ $(\mathrm{w} / \mathrm{v})$ to inhibit protein degradation by adventitious microflora. The ratio of enzyme solution $(180 \mu \mathrm{g} / \mathrm{ml})$ to substrate was $0.526: 10(\mathrm{v} / \mathrm{v})$ in both cases. Samples of hydrolysates were taken after $1 \mathrm{~min}, 1 \mathrm{~h}, 3 \mathrm{~h}, 6 \mathrm{~h}$ and 10 $\mathrm{h}$, and the reaction was quenched prior to analysis via addition of double-concentrated buffer at $50 \%(\mathrm{v} / \mathrm{v})$ (McSweeney, Olson, Fox, Healy \& Hojrup, 1993) in the case of samples for electrophoresis, or via heating at $95^{\circ} \mathrm{C}$ for $30 \mathrm{~min}$ in the case of samples for RP-HPLC.

\subsection{Electrophoretic analysis}

Urea polyacrylamide gel electrophoresis (urea-PAGE) (12.5\% for the separation gel, $4 \%$ for the stacking gel and $\mathrm{pH}$ 8.9) was performed on samples of casein hydrolysates using the method of Andrews (1983) with the modifications proposed by Shalabi and Fox (1987). Electrophoresis was carried out in a Protean II xi cell vertical slab unit (Bio-Rad) using model 1000/500 as power supply. Gels were stained with Coomassie Blue G250 (Bio-Rad) following the method of Blakesley and Boezi (1977). Quantification of $\alpha_{\mathrm{s}}$ - and $\beta$-caseins was by densitometry using a Model GS-700 imaging densitometer (Bio-Rad).

\subsection{Chromatographic analysis}

Samples of hydrolysates $(2 \mathrm{ml})$ were adjusted to $\mathrm{pH}$ 4.6 by addition of $60 \mu \mathrm{l}$ of $33.3 \%(\mathrm{w} / \mathrm{v})$ acetic acid and 
held at that temperature for $10 \mathrm{~min} ; 60 \mu \mathrm{l}$ of $3.33 \mathrm{~mol} / 1$ sodium acetate were then added and the samples were held again for $10 \mathrm{~min}$; the samples were then centrifuged at $8000 \mathrm{~g}$ for $10 \mathrm{~min}$, and the supernatants were finally recovered for further analysis.

The method of Singh, Fox and Healy (1995) was used to produce the peptide profile, by RP-HPLC, of casein hydrolysates. Chromatographic analysis was performed in a Beckman system consisting of an autosampler (Model 502), a solvent delivery system with two pumps (programmable solvent Module 126), a diode array detector (Module 168) and a personal computer with the Gold ${ }^{\mathrm{TM}}$ software v. 6.01 for data acquisition and analysis. Elution was done at $30^{\circ} \mathrm{C}$ via a Lichrosorb $250 \times 4 \mathrm{~mm}$ RP-8 $(5 \mu \mathrm{m})$ column (Merck), placed after a Lichrocart 4-4 guard column (Merck), at $1 \mathrm{ml} / \mathrm{min}$ using a binary eluent: solvent $\mathrm{A}$, i.e. $0.1 \%(\mathrm{v} / \mathrm{v})$ trifluoroacetic acid (TFA) in water, and solvent B, i.e. $0.1 \%(\mathrm{v} / \mathrm{v})$ TFA in acetonitrile. The gradient pattern followed was: $100 \%(\mathrm{v} / \mathrm{v})$ A for $5 \mathrm{~min}$, a linear gradient to $50 \%(\mathrm{v} / \mathrm{v}) \mathrm{B}$ by $55 \mathrm{~min}, 50 \%(\mathrm{v} / \mathrm{v}) \mathrm{B}$ for $6 \mathrm{~min}$, a linear gradient to $60 \%(\mathrm{v} / \mathrm{v}) \mathrm{B}$ by $4 \mathrm{~min}$ and $60 \%(\mathrm{v} / \mathrm{v}) \mathrm{B}$ for $3 \mathrm{~min}$.
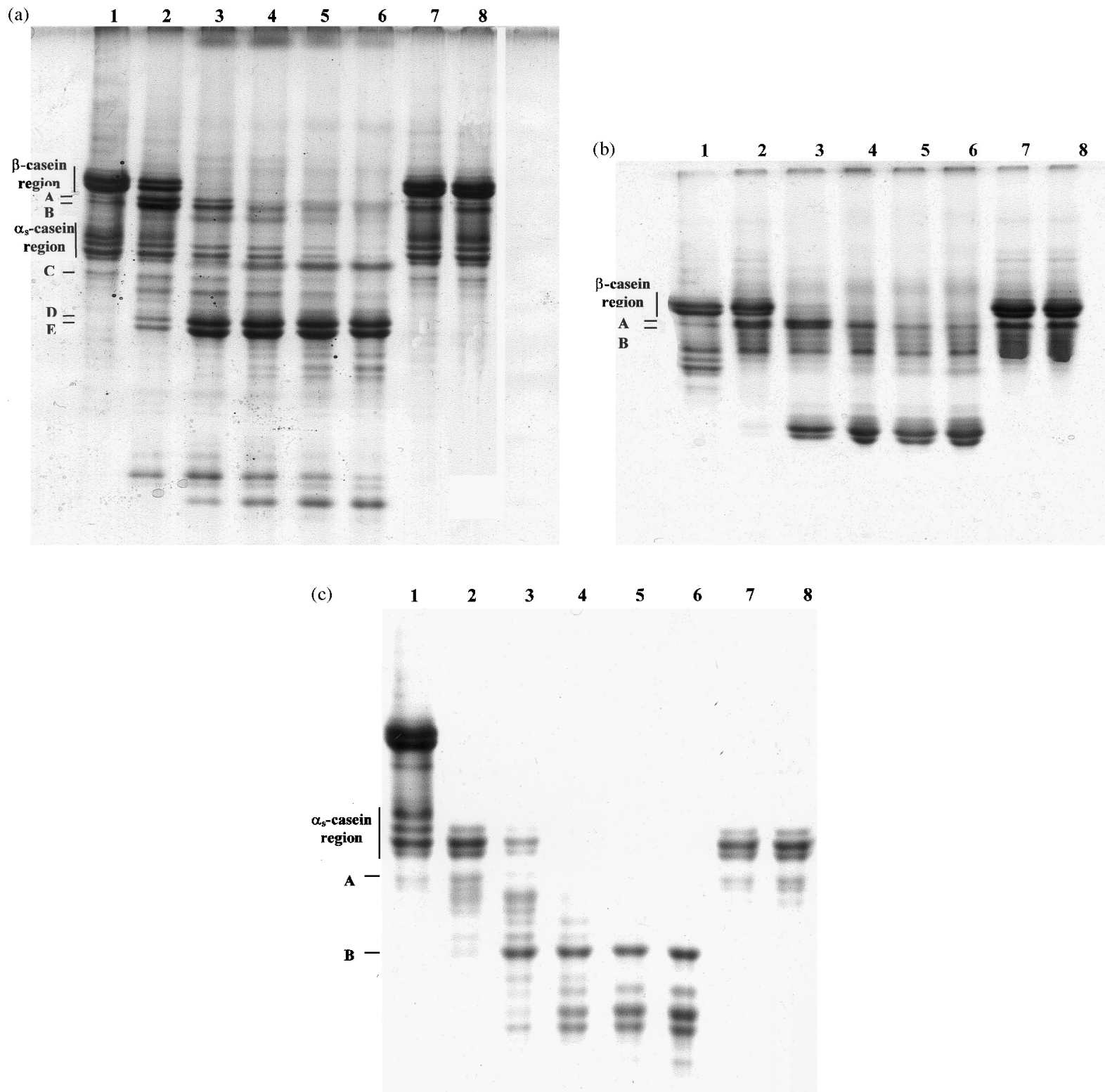

Fig. 1. Urea-PAGE electrophoregram of caprine sodium caseinate (a), pure $\beta$-casein (b) and pure $\alpha_{\mathrm{s}}$-casein (c) by $1 \mathrm{~min}, 1 \mathrm{~h}, 3 \mathrm{~h}, 6 \mathrm{~h}$ and $10 \mathrm{~h}$ (lanes 2-6, respectively) of hydrolysis by cardosin A. Plain caprine Na-caseinate was included as standard in lane 1 . Plain caprine Na-caseinate, after incubation for $1 \mathrm{~min}$ and $10 \mathrm{~h}$, was included as control in lanes 7 and 8 , respectively, of (a); plain $\beta$-casein, after incubation for $1 \mathrm{~min}$ and $10 \mathrm{~h}$, was included as control in lanes 7 and 8 , respectively, of (b); and plain $\alpha_{\mathrm{s}}$-casein, after incubation for $1 \mathrm{~min}$ and $10 \mathrm{~h}$, was included as control in lanes 7 and 8 , respectively, of (c). 
Aliquots of $100 \mu \mathrm{l}$ were injected into the RP-HPLC system and detection was by absorbance at $214 \mathrm{~nm}$.

\subsection{Sequencing analysis}

Peptides collected manually from the outlet of the RP-HPLC system were sequenced up to 5-6 residues from their $\mathrm{N}$-terminus via the Edman degradation on an automated pulsed liquid-phase protein-peptide sequencer (Applied Biosystems model 477A, Foster City, CA, USA); liberated amino acids were detected as their phenylthiohydantoin derivatives. The partial sequence thus obtained was checked against the (known) sequences of caseins so as to identify the peptide bonds cleaved by the proteinases.

\section{Results and discussion}

\subsection{Electrophoretic profiling}

Figs. 1 and 2 depict typical urea-PAGE electrophoregrams of caprine caseinate, as well as pure $\beta$-caseins and pure $\alpha_{\mathrm{s}}$-caseins, hydrolysed by cardosin $\mathrm{A}$ and $\mathrm{B}$,
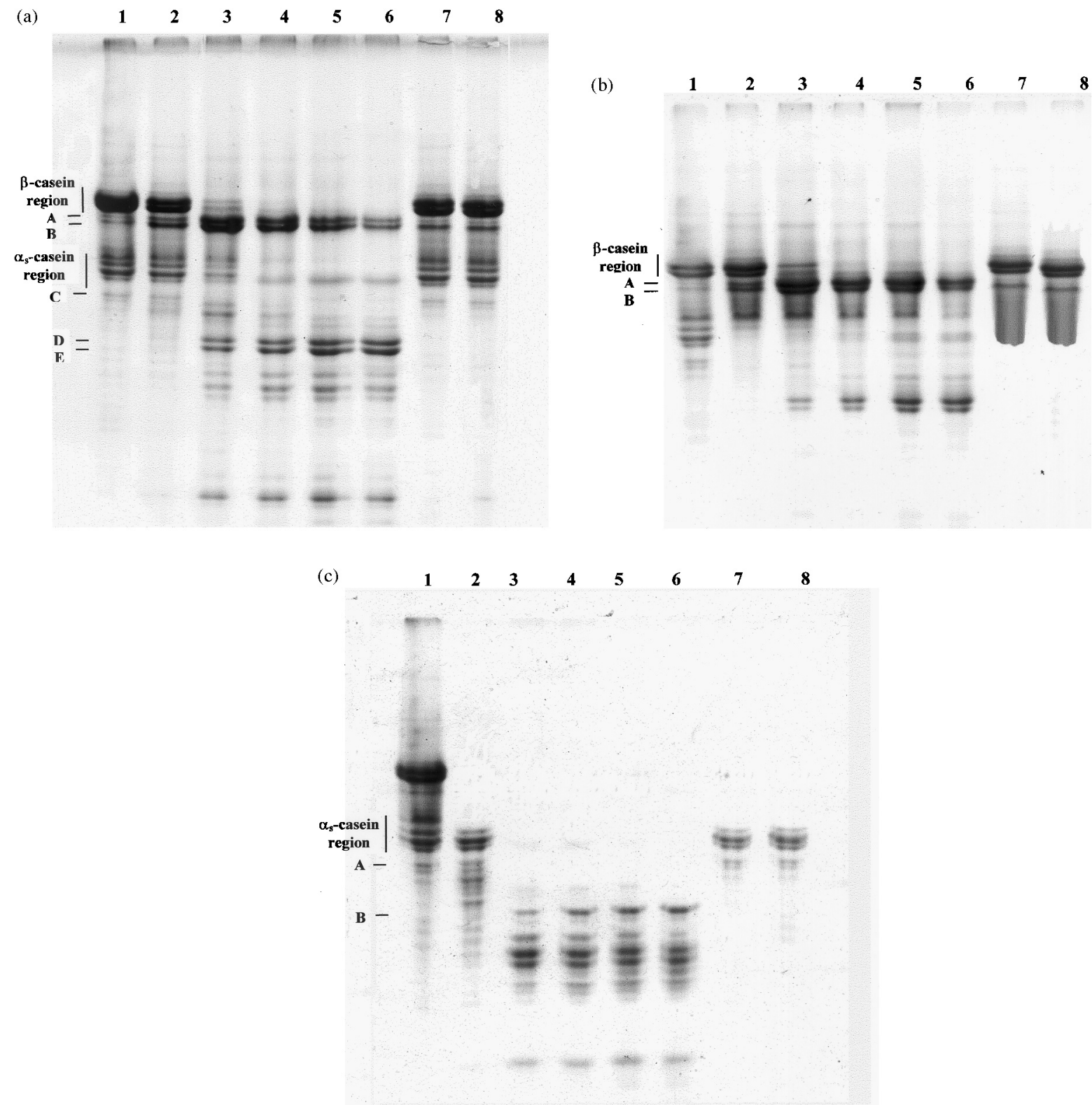

Fig. 2. Urea-PAGE electrophoregram of caprine sodium caseinate (a), pure $\beta$-casein (b) and pure $\alpha_{\mathrm{s}}$-casein (c) by $1 \mathrm{~min}, 1 \mathrm{~h}, 3 \mathrm{~h}, 6 \mathrm{~h}$ and $10 \mathrm{~h}$ (lanes 2-6, respectively) of hydrolysis by cardosin B. Plain caprine Na-caseinate was included as standard in lane 1 . Plain caprine Na-caseinate, after incubation for $1 \mathrm{~min}$ and $10 \mathrm{~h}$, was included as control in lanes 7 and 8, respectively, of (a); plain $\beta$-casein, after incubation for $1 \mathrm{~min}$ and $10 \mathrm{~h}$, was included as control in lanes 7 and 8, respectively, of (b); and plain $\alpha_{\mathrm{s}}$-casein, after incubation for $1 \mathrm{~min}$ and $10 \mathrm{~h}$, was included as control in lanes 7 and 8. respectively, of (c). 
respectively. The fractional degradation of $\beta$-casein and $\alpha_{\mathrm{s}}$-casein by each cardosin is depicted in Figs. 3 and 4 , respectively.

The group with the lowest electrophoretic mobility in Figs. 1 and 2 consists of $\beta$-casein (Richardson \& Creamer, 1974), which is sometimes subdivided into two varianting, viz: $\beta_{1^{-}}$and $\beta_{2}$-caseins (these two bands are lumped together as the $\beta$-casein region). The group of bands with the highest electrophoretic mobility is accounted for by $\alpha_{\mathrm{s}}$-caseins, and includes four different bands (also lumped together as the $\alpha_{\mathrm{s}}$-casein region); depending on the genetic protein polymorphism in goat's milk, the $\alpha_{\mathrm{s}}$ casein region may indeed include a variable number of molecular species (Boulanger, Grosclaude \& Mahé, 1984; Carretero, Trujillo, Mor-Mur \& Guamis, 1994).

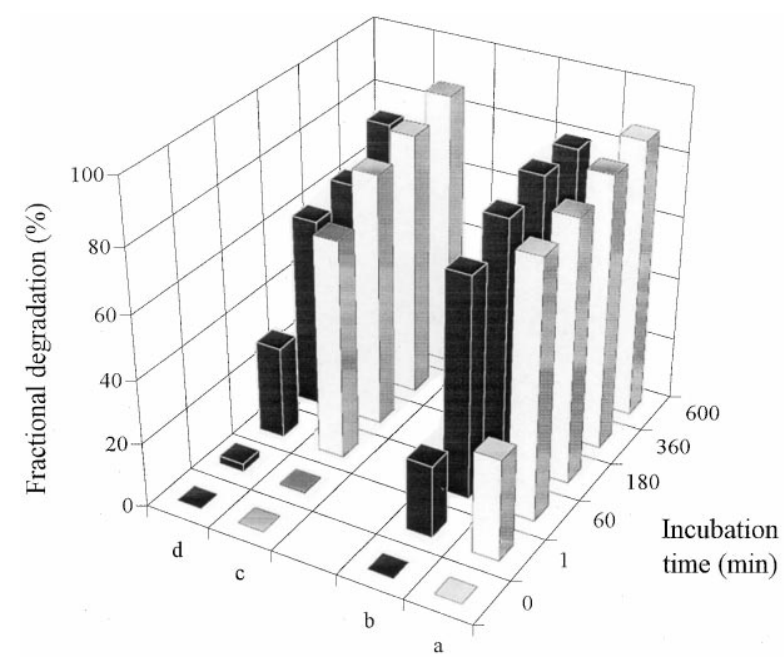

Fig. 3. Fractional degradation of $\beta$-casein in caprine caseinate and in pure form via hydrolysis effected by cardosin A (a: caseinate; b: pure) and B (c: caseinate; d: pure).

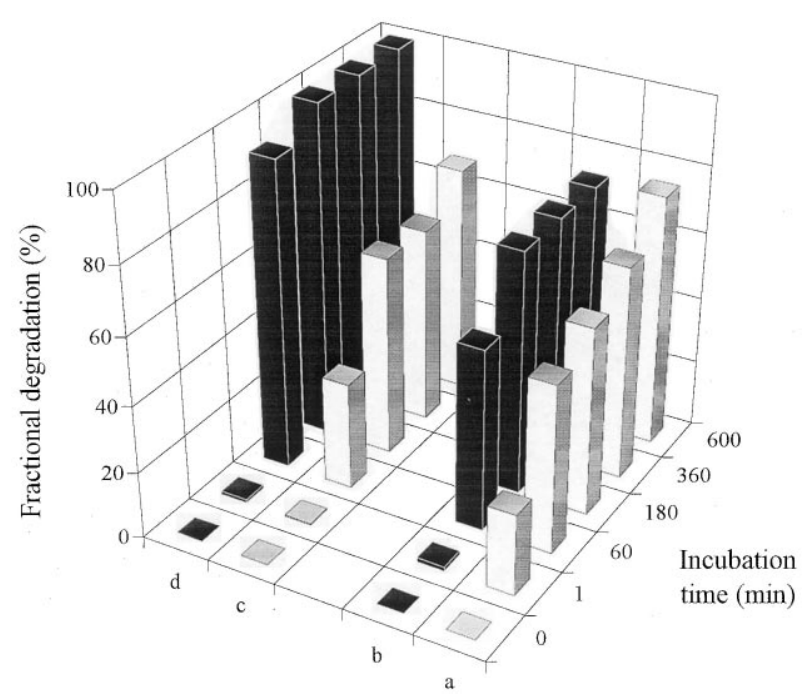

Fig. 4. Fractional degradation of $\alpha_{\mathrm{s}}$-casein in caprine caseinate and in pure form via hydrolysis effected by cardosin A (a: caseinate; b: pure) and B (c: caseinate; d: pure).
The degradation patterns of $\alpha_{\mathrm{s}^{-}}$and $\beta$-caseins, either isolated or in the presence of each other as caseinate, were similar under the action of either cardosin. $\beta$ Caseins were hydrolyzed by cardosin A or B to yield a pair of bands of higher electrophoretic mobility (denoted as bands $A$ and $B$ in lanes 2-6 of Figs. 1a, b and 2a, b), which can be noticed after as little as $1 \mathrm{~min}$ of incubation. This pair of bands is comparable to that accounted for by bovine $\beta$-I-casein (Sousa, 1993), and its existence was previously reported during proteolysis of caprine caseinate brought about by crude proteinases of $C$. cardunculus at pH 6.5 (Sousa \& Malcata, 1998), as well as for proteolysis of caseins during ripening of caprine cheeses manufactured with this plant rennet (Sousa \& Malcata, 1997a). They were also noticed in proteolysis of caprine $\beta$-caseins catalysed by calf rennet (Trujillo, Guamis \& Carretero, 1995). Studies encompassing casein breakdown in caprine cheeses by animal rennet have also reported the presence of bands accounted for by $\beta$-I-casein (Carretero et al., 1994; Marcos, Esteban, León \& Fernández-Salguero, 1978). In what concensus the catalytic activity of cardosin A upon $\beta$-caseins, bands A and B in either caprine caseinate or pure caseins tend to vanish as hydrolysis time elapses, but the opposite is observed for the action of cardosin B (see lanes 2-6 of Figs. la, b and 2a, b).

The products of degradation of $\alpha_{\mathrm{s}}$-caseins, by both cardosins $\mathrm{A}$ and $\mathrm{B}$, yielded thin bands placed right after the $\alpha_{\mathrm{s}}$-casein region (see band $\mathrm{C}$ of Figs. 1a and 2a, and band A of Figs. 1c and 2c); this band may correspond to that termed $\alpha_{\mathrm{s}}$-I-casein in the bovine counterpart, and its existence was claimed elsewhere by Sousa and Malcata (1998) during degradation of caprine caseins in solution effected by extracts of flowers of $C$. cardunculus. Studies of proteolysis of caprine caseins in distinct varieties of cheeses have also reported the existence of bands accounted for by $\alpha_{\mathrm{s}}$-I-casein (Carretero et al., 1994; Sousa \& Malcata, 1997a). The fact that these bands are not too intense is probably the result of a relatively low concentration and/or great susceptibility to further hydrolysis (Marcos et al., 1978; Freitas, Fresno, Prieto, Malcata \& Carballo, 1997). Other breakdown products are visible after $\alpha_{\mathrm{s}}$-I-casein, the number and intensity of which are different, depending on whether cardosin A or cardosin B were employed; in caseinates, two major bands appeared after the $\alpha_{\mathrm{s}}$-I-casein, which became thicker (see bands D and E in lanes 2-6 of Figs. 1a and 2a) as incubation progressed. When caseins were tested independently, one band with the same electrophoretic mobility as band E of Figs. 1a and 2a was apparent (see band B of Figs. 1c and 2c), thus suggesting that such band actually results from $\alpha_{\mathrm{s}}$-casein.

The breakdown patterns for $\beta$ - and $\alpha_{\mathrm{s}}$-caseins were rather different from one another. If caseins were mixed together in caseinate form, $\beta$-casein is degraded by both proteinases to approximately the same extent (up to 
$87 \%$ ) by $10 \mathrm{~h}$; however, proteolysis by cardosin $\mathrm{A}$ is quicker than by cardosin B (see Fig. 3). Hydrolysis of $\alpha_{\mathrm{s}}$-caseins occurred to different levels depending on the cardosin in question: $\alpha_{\mathrm{s}}$-caseins were quickly and extensively degraded by cardosin $\mathrm{A}$, reaching a percent degradation of $75 \%$ by $10 \mathrm{~h}$; within the same time frame, those caseins did undergo hydrolysis by cardosin B, but only up to $68 \%$ (see Fig. 4). These results are in agreement with those reported by Sousa and Malcata (1998): in caprine Na-caseinate, $\beta$-caseins were hydrolysed to a higher level than $\alpha_{\mathrm{s}}$-caseins at $\mathrm{pH} 6.5$ by enzymatic extracts of flowers of $C$. cardunculus.

In their pure form, $\beta$-caseins were broken down faster and more extensively by cardosin A (up to $80 \%$ within $10 \mathrm{~h}$ ) than by cardosin B (up to $73 \%$ in the same period) (Fig. 3). $\alpha_{s}$-Caseins, in pure form, were completely degraded by cardosin B by $1 \mathrm{~h}$ of hydrolysis, whereas cardosin A could only carry out $73 \%$ degradation by $10 \mathrm{~h}$ of incubation (Fig. 4).

\subsection{Chromatographic profiling}

The RP-HPLC peptide profiles of caprine caseinate, as well as of pure $\beta$ - and $\alpha_{s}$-casein, after hydrolysis for $10 \mathrm{~h}$ by cardosin A and B, are independently shown in Figs. 5, 6 and 7, respectively.
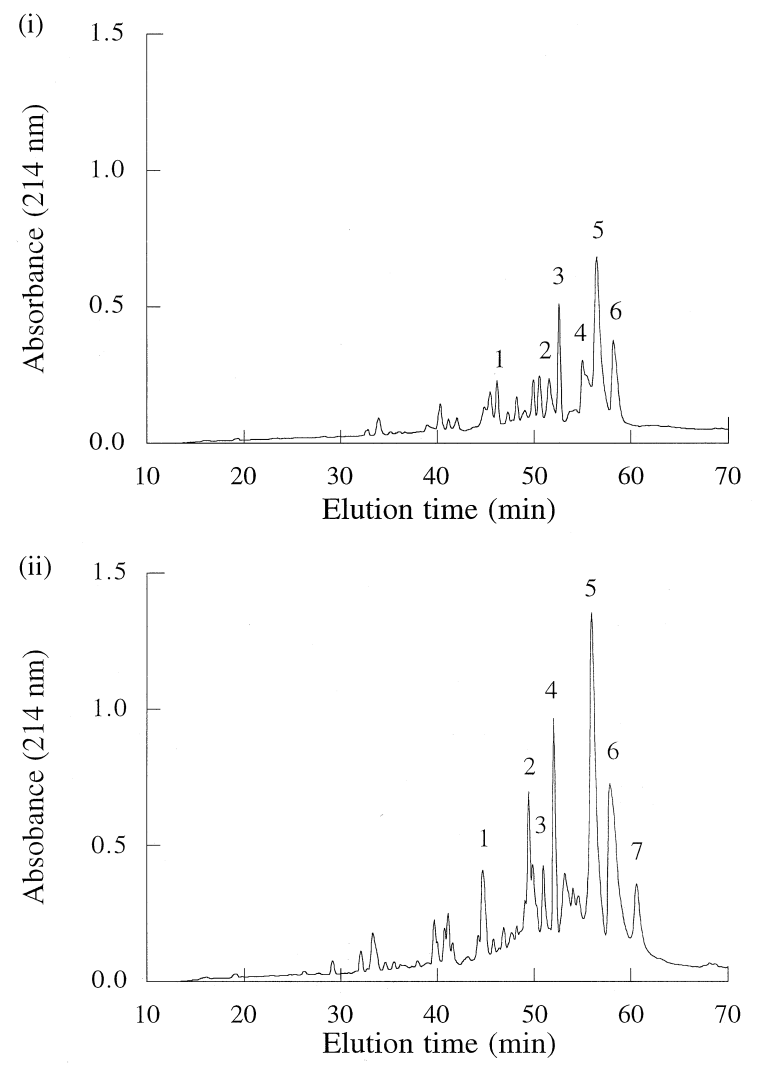

Fig. 5. RP-HPLC peptide profiles of caprine caseinate by $10 \mathrm{~h}$ of hydrolysis catalysed by cardosin A (i) and B (ii).
The peptide profiles of the caseinate hydrolysates are considerably different from one another, both qualitatively and quantitatively; by $10 \mathrm{~h}$ of hydrolysis. the number of peptides produced, via action of cardosin $\mathrm{B}$, is higher than that via action of cardosin A. This observation may be a consequence of the different specificities of these proteinases upon caprine caseins. The number of peaks produced in the hydrophobic region, i.e. with elution times between 50 and 60 min (Sousa \& Malcata, 1997b), is virtually the same for both cardosins by $10 \mathrm{~h}$ of incubation (see Fig. 5). After $10 \mathrm{~h}$, cardosin A yielded 6 major peaks, whereas cardosin B yielded 7 (see Fig. 5i, ii). Upon partial sequencing, it was concluded that cardosin A cleaved $\beta$-casein at bonds Leu190-Tyr191 and Leu127-Thr128, as derived from the $\mathrm{N}$-terminal sequences of peptides $2,3\left[\beta-\left(\mathrm{f} 191-^{*}\right)\right]$ and $5[\beta-(\mathrm{f} 128-*)]$ (see Fig. 5i). Cardosin B also cleaved the same peptide bonds, identified from the $\mathrm{N}$-terminal sequences of peptides 3, 4 [ $\beta$-(f191-*)] and 6 [ $\beta$-(f128-*)] (see Fig. 5ii). No cleavage sites were identified for $\alpha_{\mathrm{s}}$-caseins. Sousa and Malcata (1998) have reported that the major cleavage sites by cardosins in caprine caseinate are Glu100Thr101, Leu127-Thr128, Leu136-Pro137 and Leu190Tyr191 for $\beta$-casein, Phe23-Val24, Trp164-Tyr165 and Tyr173-Thr174 for $\alpha_{\mathrm{s} 1}$-casein, and Ser9-Ser10, Phe88Tyr89 and Tyr179-Leu180 for $\alpha_{\mathrm{s} 2 \text {-casein. }}$
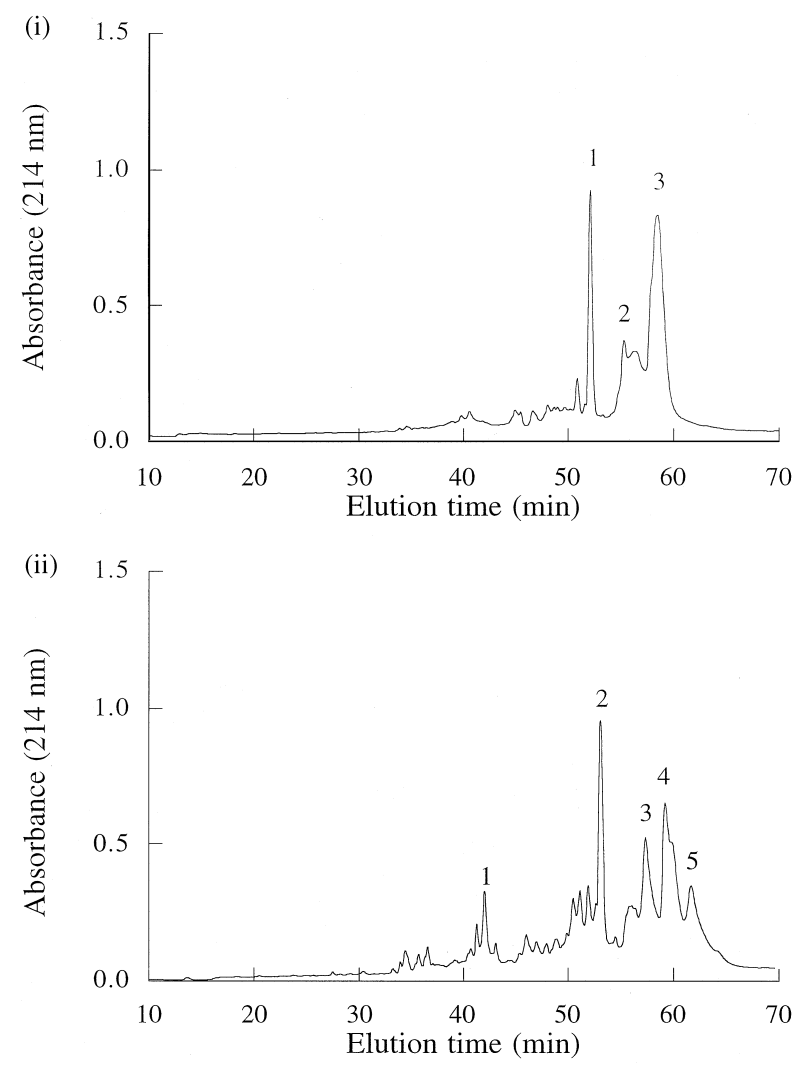

Fig. 6. RP-HPLC peptide profiles of caprine $\beta$-casein by $10 \mathrm{~h}$ of hydrolysis catalysed by cardosin A (i) and B (ii). 
With $\beta$-casein, three major peaks could be noticed after $10 \mathrm{~h}$ of hydrolysis effected by cardosin A (see Fig. 6i), whereas cardosin B yielded 5 major peaks (see Fig. 6ii). Once again, it was noticed that both enzymes cleaved the same peptide bonds, viz. Leu190-Thr191 and Leu127Thr128, as derived from the N-terminal sequence of peptides $1\left[\beta\right.$-(f $\left.\left.191-^{*}\right)\right]$ and $3\left[\beta-\left(\mathrm{f} 128-^{*}\right)\right]$ for cardosin A (see Fig. 6i), and peptides 2 [ $\beta$-(f191-*)] and 4 [ $\beta$-(f128-*)] for cardosin B (see Fig. 6ii). When bovine $\beta$-casein was tested with cardosins A and B independently, it was found that the peptide bond Leu192-Tyr193 was the most susceptible, although Leu127-Thr128 and Leu165Ser166 were also cleaved by both proteinases (Simões, 1998).

The $\mathrm{N}$-terminal sequence of caprine $\alpha_{\mathrm{s} 1}$-casein was identified in the peptides designated as $2\left[\alpha_{\mathrm{s}}-\left(1-^{*}\right)\right]$ (see Fig. 7i, ii). $\alpha_{\mathrm{s} 1}$-Casein was cleaved by cardosins A and B at Phe153-Tyr154, as again derived from the $\mathrm{N}$-terminus of peptide $1\left[\alpha_{\mathrm{s} 1}-\left(\mathrm{f} 154-^{*}\right)\right]$ (see Fig. 7i, ii). In bovine $\alpha_{\mathrm{s} 1^{-}}$ casein, both cardosins could catalyse the hydrolysis of Phe23-Phe24, Trp164-Tyr165 and Phe153-Tyr154; cardosin A also cleaved the bond Tyr165-Tyr166, while cardosin B cleaved Phe150-Arg151 (Ramalho-Santos, Veríssimo, Faro \& Pires, 1996).

Although the chromatograms depicted in Figs. 6i and $7 \mathrm{i}$, or 6ii and 7ii, do not add up to exactly obtain those
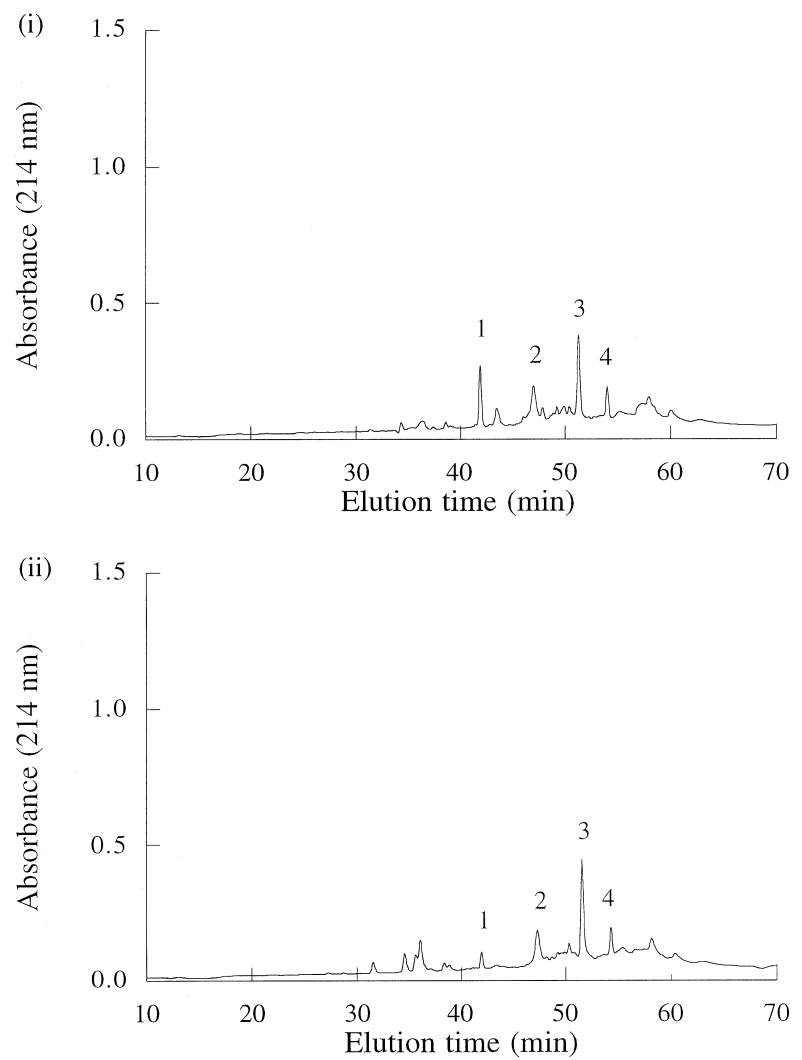

Fig. 7. RP-HPLC peptide profiles of caprine $\alpha_{\mathrm{s}}$-caseins by $10 \mathrm{~h}$ of hydrolysis catalysed by cardosin A (i) and B (ii). depicted in Fig. 5i and ii, it should be noted that caseinate also includes $\kappa$-casein in its composition (in addition to $\alpha_{\mathrm{s}^{-}}$and $\beta$-caseins), which can as well undergo hydrolysis by cardosins.

\section{Conclusions}

The degradation patterns of caprine caseins, both in caseinate form and pure form, were observed to be similar when effected by either cardosin A or B. In caseinate form, $\beta$-caseins were broken down faster by cardosin A than B, but they were eventually degraded to approximately the same extent by both proteinases; furthermore, $\alpha_{\mathrm{s}}$-caseins were quickly and extensively hydrolysed by cardosin A and less extensively by cardosin B. When caseins were tested independently, $\beta$ caseins were less extensively degraded by cardosin B than $\mathrm{A}$, whereas $\alpha_{\mathrm{s}}$-caseins were totally hydrolysed by cardosin B. Distinct peptide profiles were observed throughout hydrolysis of caseins, catalysed by either cardosin, in caseinate form and in pure form. In caseinate, the major cleavage sites by the two cardosins were Leu127-Thr128 and Leu190-Tyr191 for $\beta$-casein; both enzymes cleaved the peptide bond Phe153-Tyr154 in isolated $\alpha_{\mathrm{s1}}$-casein, and cleaved Leu127-Thr128 and Leu190-Tyr191 in isolated $\beta$-casein.

\section{Acknowledgements}

The authors are grateful to Dr. José Empis (Instituto Superior Técnico, Lisboa, Portugal) for cosupervision within the scope of the graduate program where author S.V.S. was enrolled. Financial support for S.V.S. was provided by an MSc fellowship (BM/8824/96) issued by PRAXIS XXI (FCT, Portugal). Partial financial support for this work was provided by research grants through projects PROTOLACTIS: PROdução, por Tecnologias Optimizadas, de LACticínios TradicionaIS (PAMAF, Portugal) and IMPACTO: Investigação dirigida ao Melhoramento do queijo serra Por integrAção de abordagens Científicas e TecnOlógicas (PRAXIS XXI, Portugal), both coordinated by F.X.M.

\section{References}

Andrews, A. T. (1983). Proteinases in normal bovine milk and their actions on caseins. Journal of Dairy Research, 50, 45-55.

Blakesley, R. W., \& Boezi, J. A. (1977). A new staining technique for proteolysis in polyacrilamide gels using Coomassie Brilliant Blue G250. Analytical Biochemistry, 82, 580-581.

Boulanger, A., Grosclaude, F., \& Mahé, M. F. (1984). Polymorphisme des caséines $\alpha_{\mathrm{s} 1}$ et $\alpha_{\mathrm{s} 2}$ de la chévre (Capra hircus). Génétiqie Séléction et Evolution, 16, 157-176.

Carretero, C., Trujillo, A. J., Mor-Mur, M., \& Guamis, B. (1994). Electrophoretic study of casein breakdown during ripening of goat's 
milk cheese. Journal of Agricultural and Food Chemistry, 42, 15461550.

Freitas, A. C., Fresno, J. M., Prieto, B., Malcata, F. X., \& Carballo, J. (1997). Effects of ripening time and combination of ovine and caprine milks on proteolysis of Picante cheese. Food Chemistry, 60, 219-229.

Jin, Y. K., \& Park, Y. W. (1996). SDS-PAGE of proteins in goat milk cheeses ripened under different conditions. Journal of Food Science, 61, 490-494.

Kelly, M., Fox, P. F., \& McSweeney, P. L. H. (1996). Effect of salt-inmoisture on proteolysis in Cheddar-type cheese. Milchwissenschaft, $51,498-501$.

Macedo, A., Malcata, F. X., \& Oliveira, J. C. (1993). The technology, chemistry and microbiology of Serra cheese: a review. Journal of Dairy Science, 76, 1725-1739.

McSweeney, P. L. H., Olson, N. F., Fox, P. F., Healy, A., \& Hojrup, P. (1993). Proteolytic specificity of chymosin on bovine $\alpha_{\mathrm{s} 1}$-casein. Journal of Dairy Research, 60, 401-412.

Marcos, A., Esteban, M. A., León, F., \& Fernández-Salguero, J. (1978). Electrophoretic patterns of European cheeses: comparison and quantification. Journal of Dairy Science, 62, 892-900.

Mercier, J. C., Maubois, J. L., Poznanski, S., \& Ribadeau-Dumas, B. (1968). Fractionnement préparatif des caséines de vache et brebis par chromatographie sur D.E.A.E. cellulose, en milieu urée et 2mercaptoéthanol. Bulletin de la Societe de Chimie Biologique, 50, 521-530.

Ramalho-Santos, M., Veríssimo, P., Faro, C., \& Pires, E. (1996). Action on bovine $\alpha_{\mathrm{s} 1}$ casein of cardosins $\mathrm{A}$ and $\mathrm{B}$, aspartic proteinases from the flowers of the cardoon Cynara cardunculus L. Biochimica et Biophysica Acta, 1297, 83-89.

Roseiro, M. L. B. (1991). Ewe's milk cheesemaking in Portugal using a vegetable rennet (a review). Sheep Dairy News, 8, 65-80.

Richardson, B. C., \& Creamer, L. K. (1974). Comparative micelle structure III. The isolation and chemical characterization of caprine $\beta_{1}$-casein and $\beta_{2}$-casein. Biochimica et Biophysica Acta, 365, 133137.

Robyt, J. F., \& White, B. J. (1990). Biochemical techniques - theory and practice. Prospect Heights IL: Waveland Press (pp. 213-252).

Sanjuan, E., \& Fernández-Salguero, J. (1994). Influencia de algunos factores sobre el tiempo de coagulación por cuajo vegetal (Cynara sp.). Alimentacion, Equipos y Tecnologia, 13, 69-73.

Shalabi, S. I., \& Fox, P. F. (1987). Electrophoretic analysis of cheese: comparison of methods. Irish Journal of Food Science and Technology, 11, 135-151.

Silvestre, M. P. C. (1997). Review of the methods for the analysis of protein hydrolysates. Food Chemistry, 60, 263-271.

Simões. I. I. G. (1998). Caracterização molecular da ação das cardosinas $A$ e $B$ sobre caseinas $\beta$ - $e$ - bovinas. MSc thesis, Universidade de Coimbra, Coimbra, Portugal.

Singh, T. K., Fox, P. F., \& Healy, A. (1995). Water-soluble peptides in Cheddar cheese: isolation and identification of peptides in the diafiltration retentate of the water-soluble fraction. Journal of Dairy Research, 62, 629-640.

Sousa, M. J. C. F. (1993). Plant rennet substitute from flowers of Cynara cardunculus. MSc thesis, National University of Ireland, Cork, Ireland.

Sousa, M. J., \& Malcata, F. X. (1997a). Comparative biochemical evolution during ripening of bovine and caprine cheeses manufactured with extracts of flowers of Cynara cardunculus. Zeitschrift fuer Lebensmittel-Untersuchung und Forschung A, 205, 97-103.

Sousa, M. J., \& Malcata, F. X. (1997b). Comparison of plant and animal rennets in terms of microbiological, chemical, and proteolysis characteristics of ovine cheese. Journal of Agricultural and Food Chemistry, 45, 74-81.

Sousa, M. J., \& Malcata, F. X. (1998). Proteolysis of ovine and caprine caseins in solution by enzymatic extracts from the flowers of Cynara cardunculus. Enzyme and Microbial Technology, 22, 305314.

Trujillo, A.-J., Guamis, B., \& Carretero, C. (1995). Proteolysis of goat $\beta$-casein by calf rennet under various factors affecting the cheese ripening process. Journal of Agricultural and Food Chemistry, 43, 1472-1478.

Veríssimo, P., Esteves, C., Faro, C., \& Pires, E. (1995). The vegetable rennet of Cynara cardunculus L. contains two proteinases with chymosin and pepsin-like specificities. Biotechnology Letters, 17, 621-626.

Visser, S. (1993). Proteolytic enzymes and their relation to cheese ripening and flavor: an overview. Journal of Dairy Science, 76, 329350 . 